\title{
The Relationship of Halal Food and Ibadah among Muslim Community in Malaysia
}

\author{
Mohd Al'ikhsan Ghazali1,2, Khairul Zahreen Mohd Arof ${ }^{3}$, Juhazren Juhaidi'2, Aminudin Hehsan ${ }^{1,2}$, \\ Muhammad Fathi Yusof ${ }^{3}$ and Nasikh ${ }^{4}$ \\ ${ }^{1}$ Centre of Research for Fiqh Science and Technology (CFiRST), Ibnu Sina Institute for Scientific \\ and Industrial Research (ISI-SIR), Universiti Teknologi Malaysia, 81310 Skudai, Johor, Malaysia \\ ${ }^{2}$ Faculty of Social Science and Humanities, Universiti Teknologi Malaysia, 81310 Skudai, Johor, \\ Malaysia \\ ${ }^{3}$ Razak Faculty of Technology and Informatics, Universiti Teknologi Malaysia, Kuala Lumpur, \\ Jalan Sultan Yahya Petra, 54100 Kuala Lumpur, Malaysia \\ 4Faculty of Economics, Universitas Negeri Malang, Jl. Semarang No. 5 Sumbersari Malang 65145, \\ Indonesia
}

Correspondence should be addressed to Mohd Al'ikhsan Ghazali; alikhsan.kl@utm.my

Cite this: Nusantara Halal J. 2020, Vol. 1 No.1 pp. 15-21 (Article) | Received 24 June 2020 | Revised 1 August 2020 | Accepted 2 August 2020 | Published 21 August 2020 | http://dx.doi.org/10.17977/um060.2020v1p015-021/

\begin{abstract}
Community has put the exclusive requirements for Halal food by planning the rules of manufacturing practice, in particular known as Islamic Manufacturing Practice (IMP). Many Islamic scholars mentioned the importance of Halal food to Muslim behavior, including in the practice of both Fardhu Ain and Fardu Kifayah Ibadah. This paper aims to identify the relationship of Halal food and Ibadah between the Muslim community in Malaysia. Through a questionnaire survey and systematic literature review, this study designed a set of a questionnaire survey that has passed a reliability test through a pilot study on 15 respondents with a Cronbach Alpha value 0.78 . The actual data collection consisted of 115 respondents from a random sample, which focuses only on Peninsular Malaysia. The study found that the Muslim community in Malaysia is ensuring the food intake with a Halal logo from an authorised body like JAKIM and Halal food has a weak positive relationship with Ibadah among the Muslim community in Malaysia. Unfortunately, some of the Muslim communities in Malaysia have difficulties in identifying the originality of authorized Halal logo. Therefore, this paper suggests the authorized bodies in Halal products to make a campaign in educating the Malaysian Muslim community.
\end{abstract}


Keywords: Halal food selection, ibadah, Muslim community, Islamic manufacturing practice.

\section{Introduction}

In general, Fardhu Ain means knowledge revealed, and Fardu Kifayah means knowledge acquired [1]. Firdaus describes that the holistic Islamic education aspect is the process of finding fundamental knowledge required to be learned and practiced by every Muslim [2]. On the other hand, it deals with the multilateral relationship of human and their general public, human and condition, society and condition, and comparable to Allah [1,3,4] as mentioned in the Quran verse 77 chapter 28 "But seek, with that which Allah has bestowed on you, the home of the Hereafter, and forget not your portion of lawful enjoyment in this world; and be generous as Allah has been generous to you, and seek not mischief in the land. Verily, Allah likes not the mischief-makers" (Quran 28:77).

On the other hand, the food decisions made by individuals uncover a bounteous measure of data about them like perspectives, interests, presumptions, and belief systems [5]. On top of that, [6] have proved that personality has a strong relationship with Ibadah. In these matters, this paper aims to identify the relationship of Halal food and Ibadah among the Muslim community in Malaysia. Intuitively, the Prophet Muhammad SAW has told that those who walk in path seeking knowledge, Allah will thereby make easy to them the path of paradise (Hadith narrated by Abu Hurairah). Providing Halal food to be consumed is under Fardhu Kifayah ('Aql and Mal), which can be defined as nurturing mind and wealth [7].

\section{Literature Review}

In general, the obligations of all Muslims are obeying all the command of Allah, and at the same time, the believer must stay away from all deeds that are prohibited. Among the commands is Fardu Ain, which all Muslims must know the detail and do it's following the instructions of the Prophet Muhammad SAW. The Fardu Ain like solah, siyam, zakah, and Quran recitation must be performed by all Muslims. On the other hand, Muslims are also asked to leave all the bad deeds that are prohibited. Bad deeds can be categorized into many types, but the focus of this paper is Haram food. The level of Muslims in the eyes of Allah depends on this obligation, whether they achieve the level of taqwa or not. As mentioned by Sambas [8], Takwa is the highest wisdom attained from direct spiritual experience and revealing of hijab and being in the state God Consciousness, an awareness of the existence of Allah SWT.

Not all the available food in the Malaysian market is Halal. Worst, according to Mohd Al'ikhsan and Siti Salwa [9], the integrity of workers, managers, and entrepreneurs in processing products following the Halal standard operation is doubtable. Some of the food providers are no longer practice the Halal food standard operation in the premises after receiving Halal status from authorized bodies like Jabatan Kemanjuan Islam Malaysia (JAKIM). The issue of Halal food is no longer a new concern, and according to Mohd Al'ikhsan and Siti Salwa [10], geared by the increasing population with several customs and religions, Halal issues appear in line with the progressing of labeling and branding in Halal products.

Allah SWT contended in the Quran: Surely, Salah keeps one away from shameful and evil deeds $(29,45)$. This could be understood that there is a relationship between deeds with the other 
action in human life. In this study, the relationship of Halal food and Ibadah is going to be observed. Ibadah can be defined as any type of Muslim activity which is not specifically focused on acts of ritual only [11]. This paper focuses on Fardhu Ain that specifically relates to (1) solah, (2) Quran recitation,(3) Zikr and selawat, (4) siyam, and (5) almsgiving.

Hazrat Abu Hurayra narrates: The Prophet Muhammad, please be upon him (PBUH) stated the following:

"O people, Allah is Good and He, therefore, accepts only that which is good. And Allah commanded the believers as He commanded the Messengers by saying,

"O ye messengers! Enjoy (all) things good and pure, and work righteousness: for I am wellacquainted with (all) that ye do." (23:51),

"O ye who believe! Eat of the good things that We have provided for you, and be grateful to Allah, if it is Him ye worship." (2:172). Then, he added:

"A person travels for a long time in the way of Allah, his hair disheveled and covered with dust. He lifts his hand towards the sky and makes the supplication: "O Lord, O Lord!" However, what he eats is Haram, his drink is Haram, and his clothes are Haram. How can his supplication be accepted since he feeds himself with Haram?" (Muslim, Zakah, 19; Tirmidhi, Tafsir,3; Ahmad b. Hanbal, 2/328)

A believer should make sure all the income received is from Halal (lawful) resources. Otherwise, the dua'a (prayer) will be rejected. At the end of the world before the day of the judgment, there will be Muslims who do not care about their earn, whether it is Halal or Haram. The group will eat what they desire and won't care if the food is either Halal or Haram. Many Islamic scholars mentioned this is due to the decreases in the piety. In other words, if piety decreases, the commitment of a Muslim towards religion is decreased. This had happened at our time confirming what a massage said by Prophet Muhammad PBUH "There will come a time when a man will not care how he earns his wealth, whether it comes from Halal or Haram source" narrated by Abu Hurairah may Allah blessing him. According to al-Areefi [12] if you ponder over the situation today, you will find that many people are striving in a frenzy to acquire wealth from anywhere, whether it is Halal or Haram.

\section{Methodology}

This study involved a systematic literature review and a questionnaire survey in the data collection. The systematic literature review acts as the secondary data for this study that identifies, chooses, and critically appraises previous research [13] over multiple databases and grey literature that can be replicated and reproduced by other researchers on the relationship of Halal food and Ibadah. On the other hand, a questionnaire survey was used as primary data, where the data collected from the systematic literature review were used a set of the questionnaire survey that should pass in the pilot study with minimum Cronbach's alpha value 0.7 (specifically 0.78 with 15 respondents) as recommended by Nunnally [14] and Arof et. al [15]. The questionnaire survey was then distributed to 115 random samplings respondents in 
peninsular Malaysia. The respondents consisted of 75.44 percent male (86 respondents) and 24.56 percent female ( 28 respondents). 60.87 percent ( 70 respondents) of the respondents in the age range of 41 to 60 years old. The remaining 28.70 percent ( 33 respondents), 8.70 percent (10 respondents), and 1.74 percent ( 2 respondents) are range between 21 to 40 years old, above 61 years old, and below 20 years old, respectively.

The Relative Importance Index for each un indicator under the selection of Halal food variables is calculated to examine the importance level and ranking. By identifying the importance level (RII) and rank for each sub-indicator, the awareness of the respondents can be verified [16] towards Halal food selection. Arof et. al describes that the indicator is considered to be accepted and important if the RII value is more than 70.00 [17]. The relationship between these two variables, selection of Halal food and Ibadah, was tested by using Pearson correlation test that can be simplified into negligible, weak, moderate, strong, and very strong relationships, as shown in Table 1. On the other hand, results also discussed the type of relationship explained by Mondal [18] and Bruce [19], as shown in Table 2. "0" magnitude of Correlation Coefficient shows no correlation, " +1 " indicates perfect affirmative in lines relationship as the value of one variable increases and the value of other variables also increases through a precise linear rule. Contrarily, "-1" indicates a perfect negative direct relationship as the value of one variable increases; meanwhile, the value of other variable decreases through an exact linear rule.

Table 1. Conventional approach in interpreting Correlation Coefficient

\begin{tabular}{cl}
\hline The absolute magnitude of the Correlation Coefficient & Explanation \\
\hline $0.00-0.10$ & Negligible relationship \\
$0.10-0.39$ & Weak relationship \\
$0.49-0.69$ & Moderate relationship \\
$0.70-0.89$ & Strong relationship \\
$0.90-1.00$ & Very strong relationship \\
\hline
\end{tabular}

Source: Adopted and modified from Müller and Büttner [20] and Schober et. al, [21].

Table 2. Type of relationship

\begin{tabular}{cl}
\hline The magnitude of the Correlation Coefficient & Type of Relationship \\
0 & No relationship \\
+1 & A perfect positive linear relationship \\
-1 & A perfect negative linear relationship \\
\hline
\end{tabular}

Source: Adopted and modified from Mondal [18] and Bruce [19].

\section{Results and Discussion}

This paper examined two main variables, Halal food, and Ibadah with 12 sub-indicators. This research aims to identify relationship of the first variable, Halal food, and the seconds variable, Ibadah. The Halal food selection has five sub-indicators namely; (1) HFS1= Ensuring the food is Halal, (2) HFS2= Ensuring the food with Halal logo by authorized bodies, (3) HFS3= Ensuring the restaurant with Halal logo by authorized bodies, (4) HFS4= Aware on the original and fake logo of Halal by authorized bodies, and (5) HFS5 = Not choosing food without Halal logo by authorized bodies. On the other hand, Ibadah consists of seven sub-indicators known as: (1) FAI1: Performing five daily prayers, (2) FAI2: Performing five daily prayers in Jamaah, (3) FAI3= frequently perform sunnah Prayers, (4) FAI4= Frequently recite Quran, (5) FAI5= Frequently 
Zikr to Allah and Selawat to Prophet Muhammad, (6) FAI6= Frequently perform sunnah siyam (fasting), and (7) FAI7= Frequently perform almsgiving.

This study found that the mean for both variables, namely, Halal food and Ibadah were high level with 22.60 and 28.81, respectively [9,10]. This result indicates that the Muslim community in Malaysia is still practicing Ibadah and ensuring the food consumed that is Halal by authorized bodies. Based on Table 3, all the sub-indicators have RII values more than 70.00 indicating that it is agreed and considered important by the respondents [16]. The Muslim community in Malaysia is prioritizing Halal foods in the selection (HSF1, RII=99.31), ensuring that the food is covered with Halal logo by authorized bodies like JAKIM (HSF2, RII= 94.78), ensuring the restaurant with Halal logo by authorized bodies (HSF3, RII= 93.91) and not choosing food without Halal logo by authorized bodies (HSF5, RII=85.74). Also, the Muslims in Malaysia are aware of the originality of the Halal logo by authorized bodies (HSF4, RII=78.43). Unfortunately, according to Arof et. al, [17], RII value less than 80.00 is considered not critical. This can be concluded that Malaysian Muslims are mindful of the originality of the Halal logo authorized bodies, but the knowledge differentiating originality should be improved.

Table 3. Relative importance index (RII) for Halal food selection

\begin{tabular}{llll}
\hline No & Code & RII & Rank \\
\hline 1 & HFS1 & 99.13 & 1 \\
2 & HFS2 & 94.78 & 2 \\
3 & HFS3 & 93.91 & 3 \\
4 & HFS5 & 85.74 & 4 \\
5 & HFS4 & 78.43 & 5 \\
\hline
\end{tabular}

***Indicators: HFS1 = Ensuring the food is Halal; HFS2 = Ensuring the food with Halal logo by authorized bodies; HFS3 = Ensuring the restaurant with Halal logo by authorized bodies; HFS4 = Aware on the original and fake logo of Halal by authorized bodies; HFS5 = Not choosing food without Halal logo by authorized bodies.

Table 4 illustrates the finding of the Pearson correlation test. The magnitude of the correlation coefficient and the type of each variable is explained in detail in Table 2 and Table 3, respectively. Based on the result, the selection of Halal food in Muslim daily life in Malaysia has a weak positive relationship with Ibadah as none of the variables has a Pearson Correlation magnitude of more than $0.70[20,21]$. Also, this study found that a weak positive relationship (0.35) between both Halal food and Ibadah. Although the magnitude of correlation Coefficient was low (0.35) but the positive relationship was still observed. In other words, better Halal food selection (self-control from bad deeds) is more than Ibadah performed by the Muslims community in Malaysia.

Table 4. Results from the Pearson Correlation Test

\begin{tabular}{lllllllllllll}
\hline & HFS1 & HFS2 & HFS3 & HFS4 & HFS5 & FAI1 & FAI2 & FAI3 & FAI4 & FAI5 & FAI6 & FAI7 \\
\hline HFS1 & 1.00 & 0.41 & 0.47 & 0.30 & 0.31 & 0.25 & 0.20 & 0.23 & 0.17 & 0.14 & 0.09 & 0.10 \\
HFS2 & 0.41 & 1.00 & 0.52 & 0.32 & 0.59 & 0.25 & 0.22 & 0.26 & 0.16 & 0.11 & 0.24 & 0.15 \\
HFS3 & 0.47 & 0.52 & 1.00 & 0.36 & 0.48 & 0.23 & 0.19 & 0.27 & 0.17 & 0.05 & 0.11 & 0.22 \\
HFS4 & 0.30 & 0.32 & 0.36 & 1.00 & 0.37 & 0.10 & 0.18 & 0.26 & 0.01 & 0.14 & 0.32 & 0.20 \\
HFS5 & 0.31 & 0.59 & 0.48 & 0.37 & 1.00 & 0.25 & 0.19 & 0.23 & 0.09 & 0.14 & 0.22 & 0.17 \\
FAI1 & 0.25 & 0.25 & 0.23 & 0.10 & 0.25 & 1.00 & 0.25 & 0.27 & 0.32 & 0.16 & 0.11 & 0.09 \\
\hline
\end{tabular}




\begin{tabular}{lllllllllllll}
\hline FAI2 & 0.20 & 0.22 & 0.19 & 0.18 & 0.19 & 0.25 & 1.00 & 0.61 & 0.45 & 0.36 & 0.25 & 0.27 \\
FAI3 & 0.23 & 0.26 & 0.27 & 0.26 & 0.23 & 0.27 & 0.61 & 1.00 & 0.48 & 0.60 & 0.56 & 0.38 \\
FAI4 & 0.17 & 0.16 & 0.17 & 0.01 & 0.09 & 0.32 & 0.45 & 0.48 & 1.00 & 0.51 & 0.36 & 0.23 \\
FAI5 & 0.14 & 0.11 & 0.05 & 0.14 & 0.14 & 0.16 & 0.36 & 0.60 & 0.51 & 1.00 & 0.45 & 0.34 \\
FAI6 & 0.09 & 0.24 & 0.11 & 0.32 & 0.22 & 0.11 & 0.25 & 0.56 & 0.36 & 0.45 & 1.00 & 0.26 \\
FAI7 & 0.10 & 0.15 & 0.22 & 0.20 & 0.17 & 0.09 & 0.27 & 0.38 & 0.23 & 0.34 & 0.26 & 1.00 \\
\hline
\end{tabular}

${ }^{* * *}$ Indicators: HFS1 $=$ Ensuring the food is Halal; HFS2 = Ensuring the food with Halal logo by authorized bodies; HFS3 = Ensuring the restaurant with Halal logo by authorized bodies; HFS4 = Aware on the original and fake logo of Halal by authorized bodies; HFS5 = Not choosing food without Halal logo by authorized bodies; FAI1: Performing five daily prayers; (2) FAI2: Performing five daily prayers in Jamaah; FAI3 = Frequently perform sunnah Prayers; FAI4 = Frequently recite Quran; FAI5 = Frequently Zikr to Allah and Selawat to Prophet Muhammad; FAI6 = Frequently perform sunnah siyam (fasting); and FAI7 = Frequently perform almsgiving.

\section{Conclusions}

This study found that Halal food selection has a weak positive relationship with Ibadah among the Muslim community in Malaysia. It also discovers that Muslims in Malaysia choose Halal food and this community even ensures that the food has a logo from the authorized body like JAKIM. Unfortunately, some of the Muslim communities in Malaysia have difficulties in differentiating the originality of the authorized Halal logo. Therefore, this paper suggests the authorized bodies for Halal products to make a campaign in educating the Malaysian Muslim community on this matter. On top of that, state Islamic departments through an Islamic religious center, school, higher education, and mass media should use support for this campaign.

\section{Conflicts of Interest}

The authors pronounce no conflict of interest concerning the publication of this paper.

\section{Acknowledgments}

The authors would like to express their genuine gratitude to the Ministry of Education Malaysia, Universiti Teknologi Malaysia (UTM) and the Research Management Centre (RMC) of UTM for providing the financial support for this paper to be published. This study is financed by the UTMER Grant under the cost centre PY/2019/01412 and Q.K130000.2653.18J53.

\section{References}

[1] M. S. Salleh, "Religiosity in development: A theoretical construct of an Islamic-based development," Int. J. Humanit. Soc. Sci., vol. 2, no. 14, pp. 266-274, 2012.

[2] R. Firdaus, "Educational philosophy in Islam in the curriculum design of integrated Islamic education in Malaysia," Hikmatuna, vol. 5, no. 1, pp. 1-14, 2019.

[3] R. M. Ramli, A. G. Ismail, and M. Tasrif, "M-Dex among the Islamic countries," Policy Rountable Discussion on Maqasid Shariah, Malaysia. pp. 1-28, 2015.

[4] M. Ali, Malaysia's Islam Hadhari and the role of the nation-state in international relations. London: Palgrave Macmillan, 2016.

[5] S. Riya, "Food \& identity: Food studies, cultural \& personal identity," JIntI Cult Stud, vol. 8. pp. $1-7,2018$.

[6] N. A. H. Ismail, M. Tekke, N. Othman, and A. A. R. Al-Hafiz, "Students' Islamic personality on ibadah: A structural modelling approach,” Procedia-Social Behav. Sci., vol. 219, no. May, pp. 755-761, 2016.

[7] P. Temporal, Branding for the public sector: Creating, building and managing brands people will value. John Wiley \& Sons, 2014. 
[8] S. Wiradisuria, "Menggapai kesembuhan sebuah harapan dan peluang menapaki jalan kebahagiaan," Jakarta: Paramedia Komunikatama. 2016.

[9] S. S. M. Sawari and M. A. I. Ghazali, "Mengglobalisasikan sistem piawaian standard halal Malaysia di peringkat dunia," Sains Humanika, vol. 5, no. 3, pp. 15-20, 2015.

[10] S. S. M. Sawari and M. A. I. Ghazali, "Amalan standard halal di negara-negara asia tenggara (The practices of halal standard in Southeast Asian countries)," Umr. J. Islam. Civilizational Stud., vol. 1, no. 1, pp. 35-44, 2014.

[11] M. J. Salleh, "The Integrated Islamic Education: Principles and needs for thematic approaches," in Singapore Islamic Education System (SIES) Seminar, 2009, vol. 14, pp. 1-13.

[12] M. ibn 'Abd al-R. al-'Areefi, The end of the world signs of the hour, major or minor. Darussalam, 2010.

[13] A. Dewey and A. Drahota, "Introduction to systematic reviews: online learning module cochrane training." 2016.

[14] J. C. Nunnally and I. H. Bernstein, Psychometric theory, 226th ed. New York: McGraw-Hill, 1967.

[15] K. Z. M. Arof, S. Ismail, C. Subramaniam, S. Azman, W. N. M. W. M. Rani, and M. F. Zolkepli, "Critical strategies for construction players in the adoption of biophilic city concept in Malaysia,” Plan. Malaysia, vol. 18, no. 11, pp. 181-192, 2020.

[16] K. Z. M. Arof, S. Ismail, and A. L. Saleh, "Current practice, understanding and perception on contractor's performance appraisal system in the Malaysian construction industry.," in The 2ndInternational Conference on Architecture and Civil Engineering (ICACE 2018), 2018.

[17] K. Z. M. Arof, S. Ismail, and A. L. Saleh, "Critical success factor towards the efficiency of contractor's performance appraisal system in the malaysian construction industry," Indian J. Public Heal. Res. Dev., vol. 9, no. 11, pp. 1187-1206, 2018.

[18] H. Mondal and S. Mondal, "Sample size calculation to data analysis of a correlation study in Microsoft Excel®: A hands-on guide with example," Int. J. Clin. Exp. Physiol., vol. 3, no. 4, pp. 180-189, 2016.

[19] B. Ratner, "The correlation coefficient: Its values range between+ $1 /-1$, or do they?," $J$. targeting, Meas. Anal. Mark., vol. 17, no. 2, pp. 139-142, 2009.

[20] R. Müller and P. Büttner, "A critical discussion of intraclass correlation coefficients," Stat. Med., vol. 13, no. 23-24, pp. 2465-2476, 1994.

[21] P. Schober, C. Boer, and L. A. Schwarte, "Correlation coefficients: appropriate use and interpretation,” Anesth. Analg., vol. 126, no. 5, pp. 1763-1768, 2018.

\section{Corresponding author biography}

Mohd Al'Ikhsan Ghazali is a senior lecture at Centre of Research for Fiqh Science \& Technology (CFiRST), Ibnu Sina Institute for Scientific and Industrial Research, Universiti Teknologi Malaysia (UTM). He received his Ph.D. degree from Universiti Kebangsaan Malaysia (UKM) in 2010. His specialty is in hadith and Islamic studies. 